\title{
Prospects for the use of solar energy in the Irkutsk Region and the Republic of Buryatia
}

\author{
Kuznetsova O.S., ${ }^{1,}$, Khanaev V.V. ${ }^{1}$ \\ ${ }^{1}$ Melentiev Energy Systems Institute of Siberian Branch of the Russian Academy of Sciences, 664033, Russian Federation, Irkutsk, \\ Lermontov St., 130.
}

\begin{abstract}
Due to the ever-increasing volume of energy consumption, the number of power plants capable of generating the necessary amount of electrical energy inevitably increases. The development and construction of new renewable energy sources and distribution generation facilities, the increase in electricity consumption and the growth of the tariff stimulates the search for effective technological solutions. Also in connection with the increasing popularity and improvement of technologies, there is a natural need to assess the prospects and potential opportunities of SES in the region as a whole, and for the Irkutsk region and the Republic of Buryatia, in particular.
\end{abstract}

At now, the introduction of social norms of electricity consumption is being discussed, the consequence of which will be a state of shortage of cheap electricity for private households. The possibility of equalization of tariffs is also being considered and in the departure of the Irkutsk region from the privileged position in the field of electricity supply, which will also have a negative impact on the private sector, which due to low electricity prices, makes maximum use of electricity supply resources. I would also like to mention the problems with gasification of our region. The Irkutsk region, being one of the main suppliers of gas to the world market, has virtually no access to this resource for domestic use and is forced to use electricity for heating. Any changes in this area could be catastrophic for most of the population.

When using renewable sources, in particular - solar electricity, the main problems are the high cost of generated electricity and the need to accumulate it due to the instability of the characteristics of solar insolation. In order to be able to predict the reliability of electricity generation and to estimate the value of its cost, the most accurate assessment of solar energy potential is required. For all models of solar radiation estimation, the main source of data are long-term observations of terrestrial weather stations as well as satellite observations. There are several climate databases that collect information from satellite measurements, such as ERA5, SARAH-E, NASA Power, CLARA-A, which provide average daily or monthly values, which often reduces the accuracy of the model. At the same time, data of ground-based meteorological stations can be found in open access on various Internet resources or in specialized directories. Consequently, the assessment of solar radiation because of data from weather stations, which are in the public domain, has certain advantages [1].
Solar thermal and power generation systems collect and concentrate sunlight to produce the hightemperature heat required to generate electricity. All solar energy systems have solar collectors consisting of two main components: reflectors (mirrors) that capture and focus sunlight on the receiver. In most types of systems, coolant is heated and circulated in the receiver and used to produce steam. The steam is converted to mechanical energy in a turbine, which drives a generator to produce electricity. Solar thermal power plants are equipped with tracking systems that allow sunlight to be directed to the receiver throughout the day as the sun's position in the sky changes. Solar power plants usually have a large field or array of collectors that supply heat to the turbine and generator. Some solar thermal power plants have two or more solar power plants with separate arrays and generators.

Likewise, solar thermal power plants may also have a thermal energy storage system component that allows the solar collector system to heat the energy storage system during the day, and the heat from the storage system is used to generate electricity in the evening or during cloudy weather. Solar power plants can also be hybrid systems that use other fuels (usually natural gas) to supplement solar energy during periods of low solar radiation.

There are several types of concentrating solar power plants, of which we can distinguish

Three main types of concentrating solar power plants:

- Linear concentrating systems, which include parabolic troughs and linear Fresnel reflectors.

- Solar energy towers

- Solar dish/motor systems

Linear concentrating systems collect solar energy using long, rectangular, curved (U-shaped) mirrors. The

\footnotetext{
*Corresponding author: oliv.smith@bk.ru
} 
mirrors focus sunlight onto receivers (tubes) that run the length of the mirrors. Concentrated sunlight heats the fluid flowing through the tubes. The liquid is sent to a heat exchanger to boil water in a conventional steam turbine generator to produce electricity. There are two basic types of linear concentrator systems: parabolic trough systems, where the receiving tubes are located along the focal line of each parabolic mirror, and linear Fresnel reflector systems, where one receiving tube is located over multiple mirrors, allowing the mirrors to track sunlight more mobile.

A linear concentrating collector power plant has a large number, or field, of collectors arranged in parallel rows that are usually aligned in a north-south orientation to maximize solar energy collection. This configuration allows the mirrors to follow the sun from east to west throughout the day and continuously concentrate sunlight on the receiving tubes.

\section{Parabolic Troughs}

The parabolic trough collector has a long, parabolicshaped reflector that focuses the sun's rays on the receiving tube, which is located in the center of the parabola. The collector tilts with the sun so that sunlight is focused on the receiver as the sun moves from east to west during the day.

Because of its parabolic shape, the trough can focus sunlight from 30 times to 100 times its normal intensity (concentration factor) on a receiver tube located along the focal line of the trough, reaching operating temperatures over $750^{\circ} \mathrm{F}$.

Power plant with parabolic trough

Source: Stock photo (copyright retained)

Parabolic Trough Line Concentration Systems are used in the world's longest-running solar thermal power plant, the Solar Energy Generation System (SEGS). Together, the seven SEGS III-IX power plants currently in operation have a total net summer electric capacity of about $356 \mathrm{MW}$, making them among the largest solar thermal power plants in the world.

Linear Reflector Fresnel (LFR) systems are similar to parabolic trough systems in that the mirrors (reflectors) concentrate sunlight onto the receiver above the mirrors. These reflectors use the Fresnel lens effect to produce a concentrating mirror with a large aperture and short focal length. These systems are capable of concentrating solar energy to about 30 times its normal intensity. Compact Linear Fresnel Reflectors (CLFRs)-also called concentrating linear Fresnel reflectors-are a variation of LFR technology that has multiple absorbers in close proximity to the mirrors. The multiple absorbers allow the mirrors to change their tilt in order to minimize the degree to which they block sunlight from reaching neighboring reflectors. This positioning increases system efficiency and reduces material requirements and costs.

Solar energy towers

A solar power tower system uses a large field of flat, sun-tracking mirrors, called heliostats, to reflect and concentrate sunlight to a receiver at the top of the tower. The sunlight can be concentrated 1,500 times. Some energy towers use water as the heat transfer medium. Advanced projects experiment with molten nitrate salt because of its superior heat transfer and energy storage capabilities. Its ability to store thermal energy allows the system to generate electricity during cloudy weather or at night.

Solar dish/engine systems use mirror dishes, similar to very large satellite dishes. To keep costs down, a mirror antenna usually consists of many small flat mirrors formed in the shape of a dish. The dish-shaped surface directs and concentrates sunlight to a heat receiver, which absorbs and collects the heat and transmits it to the engine generator. The most common type of heat engine used in plate/engine systems is the Stirling engine. This system uses fluid heated by a receiver to move pistons and create mechanical energy. The mechanical energy drives a generator or alternator to generate electricity.

Solar panel/motor systems always point directly at the sun and concentrate solar energy at the battery's focal point. The concentration factor of a solar panel is much higher than that of linear concentrating systems, and the operating fluid temperature is above $1,380^{\circ} \mathrm{F}$.

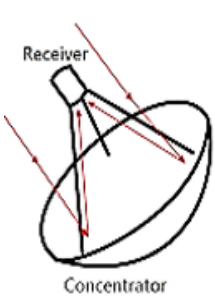

Dish

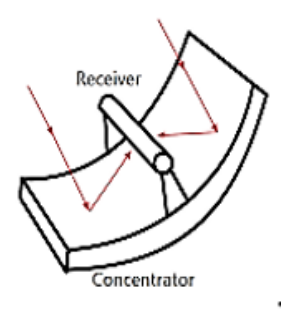

Trough

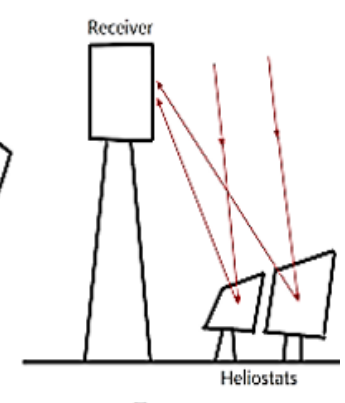

Tower
Fig. 1. The appearance of the solar panel depending on the type.

The energy generating equipment used in solar dishes can be installed at the focal point of the dish, making them well suited for remote locations, or energy can be collected from multiple installations and converted to electricity at a central location.

On the territory of Siberia, the most promising and developing renewable energy source can be considered solar power plants (SPP). This renewable source has a number of advantages. One of them is environmental safety in the place of generation, which is an important factor when choosing this type of generation out of all possible renewable energy sources present in the market at the moment. When choosing a source of generation plays an important role geographical location and climatic features. Due to the vast territory of our country, the distribution of solar energy is very diverse.

On the territory of the Russian Federation, the regions with the highest insolation indices and relatively high daylight hours are the Republic of Buryatia and the Irkutsk region, which suggests the efficient operation of solar power plants.

So thanks to the favorable geographical location duration of sunshine in the study area takes values (2000-2400 hours per year) and the intensity of solar radiation varies $\left(4-4.5 \mathrm{kWh} / \mathrm{m}^{2} *\right.$ day). 


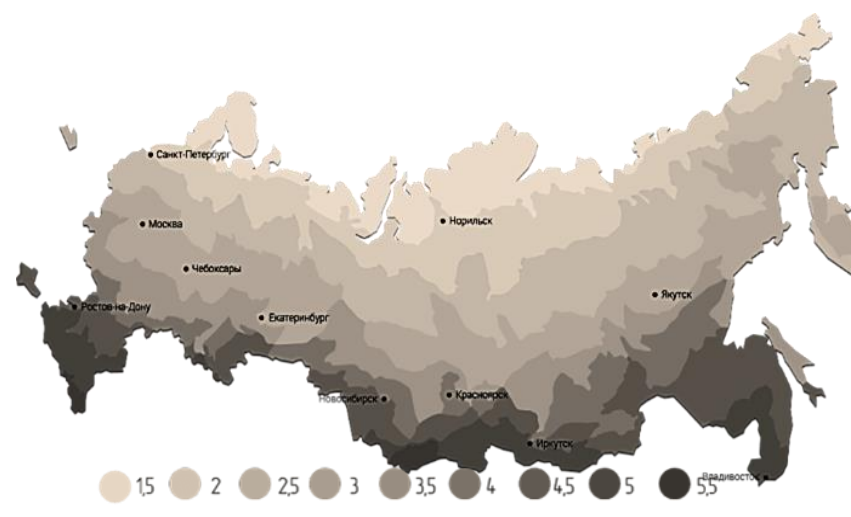

Fig. 2. Average insolation indices for the territory of the Russian Federation.

If you consider the obtained insolation data in the planning of infrastructure changes in the field of construction and electricity generation, it is possible to achieve a significant increase in generating capacity directly to consumers or, the so-called distributed generation. Analysis of potential efficiency, development and modernization of SPP in the future can lead to an increase in the number of SPP in the region, which will reduce the negative manifestations of electricity generation at its ever-increasing values.

Table 1. Solar insolation data.

\begin{tabular}{|l|c|c|c|c|}
\hline \multirow{2}{*}{} & \multicolumn{2}{|c|}{$\begin{array}{c}\text { Solar insolation } \\
\mathrm{kWh} / \mathrm{m}^{2}\end{array}$} & \multicolumn{2}{c|}{$\begin{array}{c}\text { Optimal tilt } \\
\text { angle, }\end{array}$} \\
\cline { 2 - 5 } & $\begin{array}{c}\text { Irkutsk } \\
\text { region }\end{array}$ & $\begin{array}{c}\text { Buryat } \\
\text { Republi } \\
\mathrm{c}\end{array}$ & $\begin{array}{c}\text { Irkuts } \\
\mathrm{k} \\
\text { regio } \\
\mathrm{n}\end{array}$ & $\begin{array}{c}\text { Buryat } \\
\text { Republi } \\
\mathrm{c}\end{array}$ \\
\hline January & 1,65 & 1,84 & 74 & 70 \\
\hline February & 2,98 & 2,66 & 66 & 61 \\
\hline March & 4,43 & 3,52 & 53 & 47 \\
\hline April & 5,29 & 4,54 & 38 & 32 \\
\hline May & 5,58 & 5,84 & 21 & 19 \\
\hline June & 5,73 & 6,42 & 12 & 13 \\
\hline July & 5,61 & 6,04 & 18 & 16 \\
\hline August & 4,73 & 5,37 & 28 & 29 \\
\hline September & 3,50 & 4,44 & 46 & 44 \\
\hline October & 2,43 & 3,22 & 60 & 58 \\
\hline November & 1,85 & 2,12 & 72 & 67 \\
\hline December & 1,14 & 1,77 & 76 & 73 \\
\hline $\begin{array}{l}\text { Yearly } \\
\text { average }\end{array}$ & 3,75 & 3,99 & 46,8 & 44 \\
\hline & & & & \\
\hline
\end{tabular}

Nevertheless, while one of the main problems of SPS remains the currently high cost of electricity generated by them, the intensive development of these sources of electricity remains under question. In addition, the need to accumulate electricity due to the instability of the indicators of incoming solar energy causes a number of problems in the operation of solar power plants.
Problems arise in energy harvesting technology due to the irregularity of the energy flow to the solar panels. Therefore, solar panels are used either in conjunction with energy accumulators or as a means of additional recharge for the main energy plant.

Solar insolation data and the optimal solar panel angle for the study area are necessary to be able to predict the reliability of the power generation and to estimate the cost value needed to most accurately estimate the potential of the solar power installation. For all models of solar radiation estimation, the main source of data are multi-year observations of ground-based weather stations, as well as satellite observations [2, 3].

Therefore, the assessment of solar radiation based on publicly available data from weather stations has certain advantages. Data on insolation and optimal tilt of the solar panel, depending on the month, in the regions studied presented in Table 1.

So based on the observations we can conclude that the peak insolation values are reached in the period from April to July, inclusive, and range from 5.29 to 5.73 $\mathrm{kWh} / \mathrm{m}^{2}$ for the Irkutsk region, and from May to August for the Republic of Buryatia with values from 5.37 to $6.42 \mathrm{kWh} / \mathrm{m}^{2}$.

The lowest intensity in December - January, when 1 square meter of the surface accounts for 1.77 to 1.84 $\mathrm{kWh} /$ day, for the Republic of Buryatia and 1.14 to 1.65 $\mathrm{kWh} /$ day, for the Irkutsk region [4].

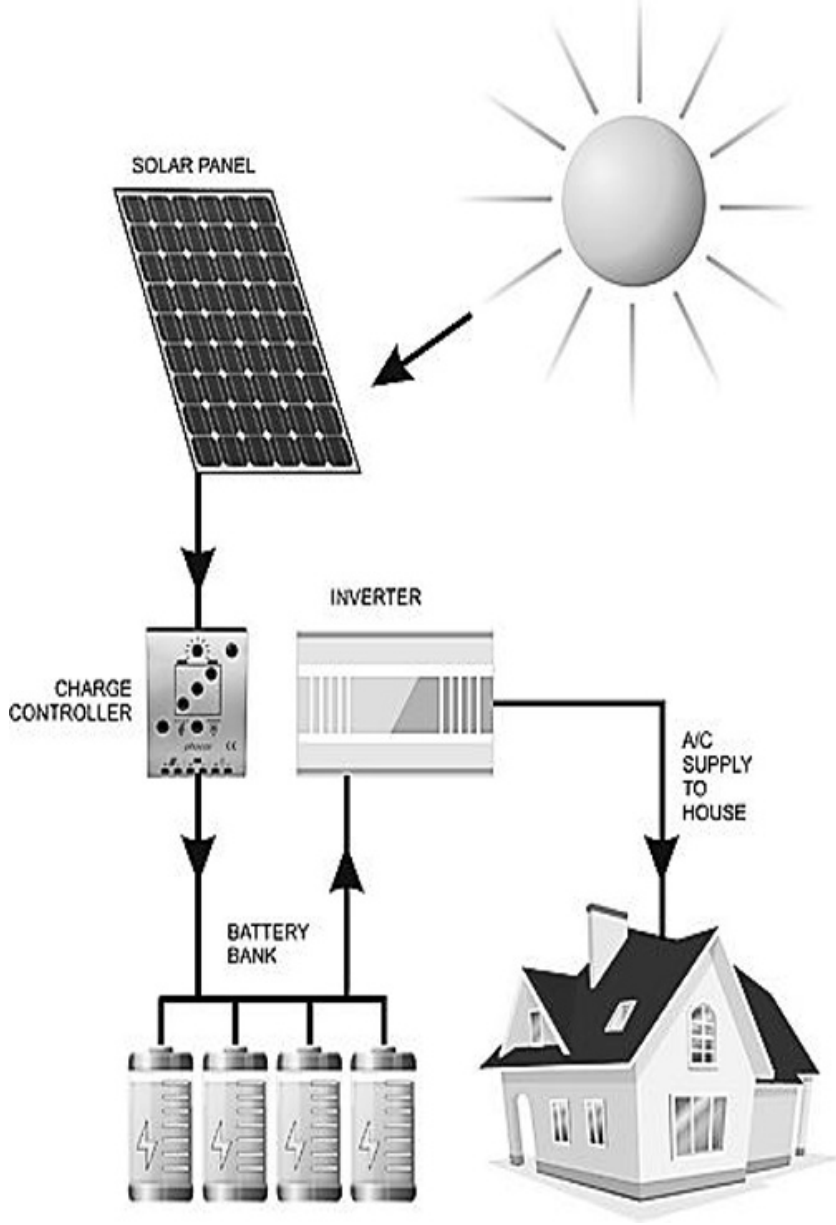

Fig. 3. Application of SES in a private household. 
Despite advanced technologies and innovations, it has not yet been possible to fully replace traditional generation sources with SES. The reason is simple. The sun only shines during the day. At night, there is no solar radiation. Accordingly, solar collectors for heating will only work during daylight hours. Although in cloudy weather the solar panels will continue to work, the heat output will be significantly reduced.

Thermal efficiency is largely influenced by the intensity of ultraviolet radiation. In areas of the far north, the power and heat output of a solar collector will be less than in regions with moderate climates.

Heating by means of solar panels is used exclusively as an additional source of heat. The operating principle of the collector is based on the conversion of ultraviolet radiation into thermal energy.

The resulting heat is sent to the store - a buffer tank installed inside the building. In air systems there is no liquid coolant. Heated air masses are blown into the room with the help of fans.

If you consider that the efficiency of solar collectors in winter significantly decreases, the autonomous heating of the house requires proper calculations. Experts recommend at the planning stage to install a heat source on traditional energy carriers (gas, wood, pellets, coal, diesel fuel, electricity), able to meet $100 \%$ of the building's heating and hot water needs. Solar system will use solar energy and partially offset the cost with different efficiency, depending on the month of the year.

To determine whether to install alternative heating for a private home, it is worth paying attention to the existing advantages and disadvantages of solar collectors. When compiling a table of pros and cons, it is necessary to consider the real reviews of solar systems left by users:

Disadvantages - the main disadvantage is the high cost (it is worth noting that with the emergence of collectors of Russian production, solar heating systems have become more economically accessible). There are several other disadvantages:

seasonality - solar collectors with vacuum thermal tubes are effective up to the ambient temperature of -50 ${ }^{\circ} \mathrm{C}$. Vacuum solar collectors will continue to work until the antifreeze in the heat exchanger freezes. Solar panel collectors operate at temperatures as low as $-25^{\circ} \mathrm{C}$.

dependence on electricity - all-season systems operate with forced circulation of the coolant. In case of power failure, the coolant can boil.

long payback - in the case of heating, the collector operation is mainly carried out at sub-zero temperatures. The thermal efficiency of the solar system is reduced. Payback period increases up to 6-7 years.

Advantages - record low temperatures in the middle latitudes are rare. During the entire heating season there is no more than a one-week period when the collectors stop working. With the right equipment selection and calculations, it is possible to find a ready-made solution that can compensate for the heating needs of a residential house to the maximum extent possible. For average latitudes, the compensation of energy costs reaches $20-30 \%$. Additional advantages: service life of
30 to 50 years, anti-vandal and anti-hail protection, solar panels withstand wind squalls.

The above general advantages and disadvantages for any system of heating a private home from solar energy[5].

After studying the insolation data obtained from publicly available sources, an abstract consumer of generating capacity was used as the basis of research, in order to theoretically design and calculate the number of necessary SPS on the selected territory and the production of possible capacities on them. A household with an area of $100 \mathrm{~m}^{2}$ was taken as a calculation unit.

Table 2. Daily energy consumption in the household.

\begin{tabular}{|c|c|c|c|c|c|}
\hline $\begin{array}{l}\text { Power } \\
\text { consumer }\end{array}$ & $\begin{array}{l}\text { Qt } \\
y\end{array}$ & $\begin{array}{l}\text { Pow- } \\
\text { er, W }\end{array}$ & $\begin{array}{l}\text { Work- } \\
\text { ing time }\end{array}$ & $\begin{array}{l}\text { Elec- } \\
\text { tricity } \\
\text { con- } \\
\text { sump- } \\
\text { tion, } \\
\mathrm{kWh} / \\
\text { day }\end{array}$ & $\begin{array}{l}\text { Daily } \\
\text { consump } \\
\text { tion } \\
\text { total, } \\
\mathrm{kWh}\end{array}$ \\
\hline $\begin{array}{l}\text { Energy- } \\
\text { saving } \\
\text { bulbs }\end{array}$ & 20 & 15 & 6 & 1,8 & $\begin{array}{l}1.8 \\
(1 \%)\end{array}$ \\
\hline $\begin{array}{l}\text { Electric } \\
\text { stove }\end{array}$ & 1 & 8000 & 2 & 16 & \multirow{5}{*}{$\begin{array}{l}19.8, \\
(9 \%)\end{array}$} \\
\hline $\begin{array}{l}\text { Refrigerat } \\
\text { or }\end{array}$ & 1 & 350 & 6 & 2,1 & \\
\hline Teapot & 1 & 1500 & 0,4 & 0,6 & \\
\hline $\begin{array}{l}\text { Microwav } \\
\text { e }\end{array}$ & 1 & 1500 & 0,2 & 0,3 & \\
\hline $\begin{array}{l}\text { Kitchen } \\
\text { appliances }\end{array}$ & 1 & 1600 & 0,5 & 0,8 & \\
\hline TV & 1 & 100 & 5 & 0,5 & \multirow{7}{*}{$\begin{array}{l}5.85 \\
(2 \%)\end{array}$} \\
\hline Computer & 1 & 250 & 5 & 1,25 & \\
\hline Iron & 1 & 2400 & 0,143 & 0,34 & \\
\hline Washer & 1 & 1500 & 0,215 & 0,32 & \\
\hline $\begin{array}{l}\text { Vacuum } \\
\text { cleaner }\end{array}$ & 1 & 2000 & 0,07 & 0,14 & \\
\hline $\begin{array}{l}\text { Charging } \\
\text { the phone }\end{array}$ & 1 & 300 & 8 & 2,4 & \\
\hline $\begin{array}{l}\text { Hairdryer / } \\
\text { electric } \\
\text { shaver }\end{array}$ & 1 & 1800 & 0,5 & 0,9 & \\
\hline $\begin{array}{l}\text { Electric } \\
\text { boiler }\end{array}$ & 1 & 8500 & 24 & 204 & \multirow{2}{*}{$\begin{array}{l}204.6, \\
(88 \%)\end{array}$} \\
\hline $\begin{array}{l}\text { Circula- } \\
\text { tion pump }\end{array}$ & 1 & 50 & 12 & 0,6 & \\
\hline $\begin{array}{l}\text { Total } \\
\text { volume } \\
\text { per day }\end{array}$ & \multicolumn{5}{|c|}{$232.05,(100 \%)$} \\
\hline
\end{tabular}

The size of the household was determined based on the constantly increasing demand for residential buildings in the private sector. In calculating the electricity consumption, the minimum required set of 
appliances that are consumers of electricity and their approximate operating hours were accounted for. Average values were taken, which took into account the peculiarities of changing consumption from one season to the next. The electricity consumption for water heating and space heating was also considered, as well as the operating time of the electrical appliances. The Table 2 shows the power values of the appliances and the operating time.

The total daily electricity consumption for a $100 \mathrm{~m} 2$ household was $232.05 \mathrm{kWh}$, of which $204.6 \mathrm{kWh}$ w

As spent on the boiler and the pump. Household consumption was $25.65 \mathrm{kWh}$, and about $1.8 \mathrm{kWh}$ of electricity was consumed for lighting.

Despite the fact that the highest load values are due to the operation of the boiler, this load requires storage costs and is a variable value, depending on the season. The load attributable to lighting, which is flexible and most amenable to modernization through the introduction of SPP, a relatively constant value.

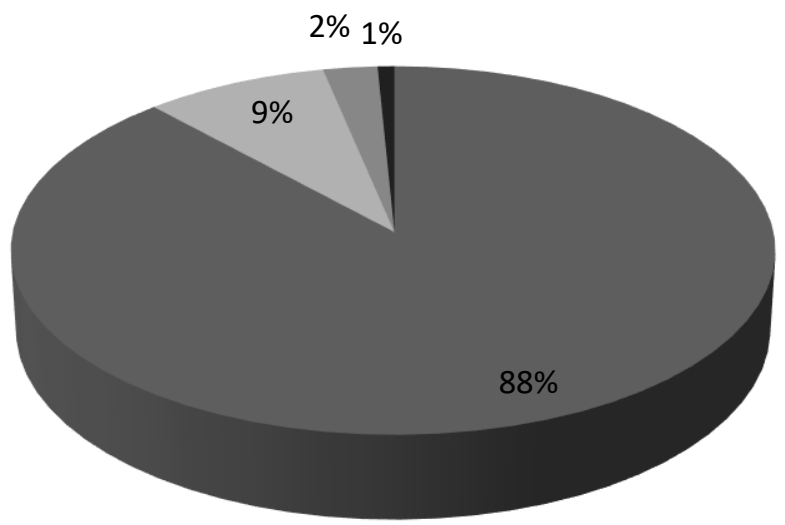

Heating

Kitchen appliances

Electrical appliances

Illumination

Fig. 4. Percentage of energy used for household lighting

The conducted studies once again confirm that it is not possible to fully provide households with electricity from the SPP because of the imperfections described earlier. The available opportunities allow providing at least the needs of lighting, and under optimal conditions of choice of SPP panels and rational and economical use of energy and some household appliances.

The main value that affects the satisfaction of the planned loads is the choice of capacity of the solar panel. Therefore, in the calculation we used the average for the Irkutsk region and the Republic of Buryatia amount of generated electricity, taking into account the choice of three different capacity solar panels with the same coverage area of $10 \mathrm{~m}^{2}$. If you install solar panels at the optimal angle for the area or models that regulate the angle of elevation automatically, you can achieve full coverage of electricity spent on lighting or even exceed the electricity needed to cover the needs of lighting.

It is conceivable that by selecting the panel with the highest estimated output, it will be possible to cover not only the load spent on lighting, but also the use of some electrical appliances. These calculations are shown in Table 3.

Table 3. Data on the generation of solar panels of different capacity.

\begin{tabular}{|l|c|c|c|}
\hline Solar battery SilaSolar, W & 250 & 350 & 450 \\
\hline January & 4,02 & 4,69 & 6,03 \\
\hline February & 5,67 & 6,62 & 8,51 \\
\hline March & 7,68 & 8,96 & 11,52 \\
\hline April & 7,59 & 8,86 & 11,39 \\
\hline May & 7,28 & 8,49 & 10,98 \\
\hline June & 6,75 & 7,88 & 10,13 \\
\hline July & 6,34 & 7,15 & 9,20 \\
\hline August & 5,99 & 6,98 & 8,98 \\
\hline September & 5,84 & 6,81 & 8,75 \\
\hline October & 5,07 & 5,92 & 7,61 \\
\hline November & 3,92 & 4,57 & 5,87 \\
\hline December & 3,30 & 3,85 & 4,95 \\
\hline $\begin{array}{l}\text { Average annual electricity } \\
\text { generation, kWh/day }\end{array}$ & 5,77 & 6,73 & 8,65 \\
\hline $\begin{array}{l}\text { Total electricity generation } \\
\text { per year of operation, kWh }\end{array}$ & 2104,44 & 2455,18 & 3156,66 \\
\hline
\end{tabular}

To make the calculations and obtain the projected values of the required additional generating capacity we used the values obtained from [6].

The result of the calculations was to obtain such values as the total amount of electricity consumed, the amount of electricity consumed for lighting needs and their total annual values (Table 4). The calculations were carried out taking into account the growth and development trends of the private sector in the selected area.

According to the results of calculations, it was found that the total annual volume of electricity used only for lighting buildings will exceed $345 \mathrm{MWh}$, and the total annual volume of electricity required to fully meet the needs of consumers will be about 46054 GWh.

One of the main conclusions of this work was that the proposed solution to the problems could be a partial replenishment of electricity from renewable resources, which will alleviate the economic and environmental situation. SPP as a source of additional generating capacity used to partially meet the needs of private sector developments may become one of the promising and promising solutions. Despite the low electricity tariffs, 
the territories of the Irkutsk Region and the Republic of Buryatia are promising for the implementation of SPP due to their favorable geographical location.

Table 4. Resulting volumes of energy consumption.

\begin{tabular}{|l|c|c|}
\hline & $\begin{array}{c}\text { Irkutsk } \\
\text { region }\end{array}$ & $\begin{array}{c}\text { Buryat } \\
\text { Republic }\end{array}$ \\
\hline Number of buildings & 525733 & 250330 \\
\hline $\begin{array}{l}\text { Total electricity } \\
\text { consumption GWh }\end{array}$ & 126.176 & 60.0793 \\
\hline $\begin{array}{l}\text { Total annual electricity } \\
\text { consumption, GWh }\end{array}$ & 46054.281 & 21928.934 \\
\hline $\begin{array}{l}\text { Total amount of electrici- } \\
\text { ty consumed by lighting, } \\
\text { MWh }\end{array}$ & 946.321 & 450.595 \\
\hline $\begin{array}{l}\text { Total annual volume of } \\
\text { electricity consumed by } \\
\text { lighting, MWh }\end{array}$ & 345.407 & 164.467 \\
\hline
\end{tabular}

It can be also noted that the calculated values of capacity can meet not only the needs of the private sector. The necessary modernization can be used when replacing the generating facilities.

\section{References}

1. Shakirov V.A., Yakovkina T.N., Kurbatsky V.G.//A Method of Estimation of Electric Power Generation by Solar Power Plants Using Data from Long-Term Observations of Meteorological Stations. Vestnik of the Irkutsk State Technical University. 2020. T. 24. № 4. C. 858-875.

2. Map of solar radiation flux // Scientific electronic library [Electronic resource]. Access mode: https://monographies.ru/ru/book/section?Id=16296

3. Map of sunshine duration // Scientific electronic library [Electronic resource]. Access mode: https://monographies.ru/ru/book/section?Id=16296

4. Value of solar insolation in Irkutsk (Irkutsk region) // Scientific electronic library [Electronic resource]. Access mode: https://www.betaenergy.ru/insolation/irkutsk/

5. Solar explained [Electronic resource]. Access mode:

https://www.eia.gov/energyexplained/solar/solarthermal-power-plants.php

6. "REGIONS OF RUSSIA SOCIAL AND ECONOMIC INDICATORS 2020": date of introduction 2021-01-01. [Electronic resource]. Access mode https://rosstat.gov.ru/folder/210/document/13206 